\title{
Impact of malocclusion severity on the quality of life of non-white adolescents
}

\author{
Impacto da severidade da má oclusão na qualidade de vida \\ de adolescentes não brancos
}

Juliana Andrade de Lacerda (https://orcid.org/0000-0001-9829-2299) ${ }^{1}$

Técia Mendes Daltro Borges (https://orcid.org/0000-0001-8647-1257) ${ }^{2}$

Marcelo de Castro Meneguim (https://orcid.org/0000-0002-1056-1288) ${ }^{3}$

Mario Vedovello Filho (https://orcid.org/0000-0001-8512-3285) ${ }^{1}$

Milton Santamaria Júnior (https://orcid.org/0000-0002-3490-5030) ${ }^{1}$

Silvia Amélia Scudeler Vedovello (https://orcid.org/0000-0002-7203-2867) ${ }^{1}$
${ }^{1}$ Programa de PósGraduação em Odontologia, Fundação Hermínio Ometto (FHO). Av. Dr. Maximiliano Baruto 500, Araras. 13607 339 São Paulo SP Brasil. silviavedovello@fho.edu.b ${ }^{2}$ Universidade Estadual de Feira de Santana. Feira de Santana BA Brasil.

${ }^{3}$ Universidade Estadual de Campinas. Campinas SP Brasil.

\begin{abstract}
The aim of this study was to evaluate the impact of malocclusion severity on the oral health-related quality of life (OHRQoL) of nonwhite adolescents. A cross-sectional study was conducted with 585 non-white Brazilian adolescents (12-15 years). The Dental Aesthetic Index (DAI) was used for the clinical assessment of malocclusion and Oral Health Impact Profile (OHIP14) on OHRQoL. Deep bite and transverse occlusal relationships were assessed in association with the DAI. The adolescents with DAI 3 and 4 were distributed into 4 groups: G1 - individuals without transverse occlusal relationships or deep bite; G2 - individuals with only posterior crossbite; G3 - individuals with only deep bite; and G4 - individuals with Brodie bite. The backward stepwise procedure was used to select variables on each level, eliminating variables with a $p \leq 0.20$. From the logistic regression analyses, the adjusted odds ratios were estimated with the respective 95\% confidence intervals. The adolescents with severe malocclusion divided into the G2, G3 and G4 showed p-value of 0.0501, 0.1475, and 0.5407, respectively, but did not remain in the final model. Malocclusion severity had no impact on the OHRQoL of non-white adolescents.
\end{abstract}

Key words Malocclusion, Quality of life, Nonwhite adolescents
Resumo O objetivo deste estudo foi avaliar o impacto da severidade da má oclusão na qualidade de vida relacionada à saúde bucal (OHRQoL) de adolescentes não brancos. Estudo transversal foi realizado com 585 adolescentes brasileiros não brancos (12-15 anos). O Índice de Estética Dental (DAI) foi utilizado para a avaliação clínica da má oclusão e o Oral Health Impact Profile (OHIP14) na OHRQoL. A sobremordida profunda e as relações oclusais transversais foram avaliadas em associação com o DAI. Os adolescentes com DAI 3 e 4 foram divididos em 4 grupos: G1 - indivíduos com relação transversal normal ou com ausência de sobremordida; G2 - indivíduos com mordida cruzada posterior; G3 - indivíduos com sobremordida profunda; e, G4 - indivíduos com mordida em Brodie. O modelo final estimou as variáveis selecionadas após o ajuste para aquelas que permaneceram no modelo multivariado em niveis iguais e superiores. A partir das análises de regressão logistica, os odds ratios foram ajustados e estimados com os respectivos intervalos de confiança de 95\%. Os adolescentes com má oclusão severa divididos em G2, G3 e G4 mostraram um p-valor de $0.0501,0.1475$, e 0.5407, respectivamente, mas não permaneceram no modelo final. A severidade da má oclusão não teve impacto na OHRQoL de adolescentes não brancos.

Palavras-chave Má oclusão, Qualidade de vida, Adolescentes não brancos 


\section{Introduction}

The individual's quality of life may be influenced by their oral condition ${ }^{1}$. In this context, studies have shown that malocclusion may lead to negative repercussion on the lives of individuals ${ }^{2-4}$, but there is still divergence about the extent to which occlusion can impact quality of life ${ }^{5,6}$. Generally, the more severe degrees of malocclusion have been observed to cause impacts, and the higher the degree of severity the greater the perception of such impact ${ }^{7}$. In addition, the negative impact is usually observed on speech, chewing and smile aesthetic perception. Thus, the association of severe malocclusion with the most unfavorable experiences regarding oral health-related quality of life (OHRQoL), especially from functional and emotional aspects ${ }^{8}$, has stood out in the literature.

Although there are different studies focusing on better understanding the epidemiological profile of severe and disabling malocclusions and their associated factors ${ }^{9}$, the implications of specific occlusal changes on OHRQoL, such as vertical and transverse problems $\mathrm{s}^{10}$, have not yet been elucidated.

The Dental Aesthetic Index (DAI) is the standard criterion that classifies malocclusion according to severity ${ }^{11}$. However, it is limited for not measuring transverse changes of deviation from the midline and deep bite ${ }^{12}$. Although these changes are not included in the DAI, such aspects may cause negative impacts on individuals ${ }^{13}$.

In this sense, it is known that crossbite may be associated with muscular changes, facial asymmetries, midline deviations, episodes of pain and discomfort, and compromised aesthetics and function of individuals ${ }^{14,15}$. In addition, in relation to transverse occlusal relationships, the Brodie bite may be related to functional changes such as temporomandibular disorders from compromised mastication ${ }^{16}$. Furthermore, tooth wear, gingival traumas, and interference with masticatory function are some of the clinical and functional problems that may be associated with deep bite ${ }^{17}$. Thus, transverse changes and deep overbite may influence the severity of malocclusion.

Moreover, epidemiological studies have pointed out that adolescents who self-reported brown or black skin had a higher chance of having severe malocclusion than those with white skin'. Brazilian individuals with brown and black skinned, generally, have lower income than those with white skin, even taking other socioeconom- ic and demographic factors such as schooling, sex, and age into account ${ }^{9,18,19}$. The socioeconomic and sociodemographic context may also influence the severity of malocclusion, with a negative impact on quality of life ${ }^{20,21}$; mainly because the malocclusions originate from the interaction between genetic and environmental factors.

Besides the lack of studies in relation to nonwhite populations, the theoretical model elaborated was based on epidemiological studies for the interaction of social and clinical factors ${ }^{9,22}$. The model hypothesizes that the association of transverse and deep bite alterations with DAI results in a greater negative impact on OHRQoL and, therefore, outline possible relations of interdependence among the variables. Thus, this study aimed to evaluate the impact of malocclusion severity, determined by DAI, associated with transverse occlusal relationship and deep bite, on the non-white adolescent's OHRQoL.

\section{Methods}

This cross-sectional study was carried out in northeastern Brazil (state of Bahia) with 585 non-white adolescents aged 12 and 15 years, enrolled only in public schools. The sample was selected in two stages. In the first stage, the public schools were randomly selected. Subsequently, the adolescents were randomly selected in each of the schools.

The sample was calculated considering a significance level of $5 \%$, test power of $80 \%$, odds ratio of 2 , and prevalence rate for very severe malocclusion of $5.4 \%$ for 12 -year-olds and $5.1 \%$ for 15 -year-olds ${ }^{9}$, resulting in a minimum sample of 217 individuals.

The study included only non-white adolescents with severe malocclusion, whose parents had authorized the examination, without previous orthodontic treatment, and free of systemic diseases or either communication or neuromotor disorders. This study was approved by the Research Ethics Committee.

For the categorization of non-white individuals, black and brown adolescents were considered. The research used the classification by the Brazilian Institute of Geography and Statistics ${ }^{23}$, considering the predominant physical features. In the population studied, there were no yellow and indigenous adolescents.

For data analysis, the independent variables of family income and parental level of education were dichotomized by the median, referenced by 
the Brazilian minimum wage in $2016(\leq \mathrm{R} \$ 880.00$ or $>\mathrm{R} \$ 880.00$ ) and education up to complete or incomplete primary school. The parents also responded whether or not the adolescent had access to dental care in the last 12 months.

The DAI was used for classifying malocclusion regarding severity and orthodontic treatment need $^{11}$. Four categories of malocclusion were established based on severity and treatment need: no malocclusion, normal or mild change/without treatment need (DAI $1<25$ ); established malocclusion/optional treatment need (DAI 2=26-30); severe malocclusion/highly desirable treatment need (DAI 3 = 31-35); disabling malocclusion/ mandatory treatment need (DAI $4 \geq 36$ ). For data analysis, only the adolescents who presented score $>30$ (DAI $\geq 3$ ) were studied. Only one previously calibrated examiner performed the examinations in all the adolescents. For intra-examiner reproducibility, the Intraclass Correlation Coefficient (ICC) was used, obtaining a value of 0.96 .

Deep bite and transverse occlusal relationships were also assessed in association with the DAI. To determine overbite, the distance from the incisal surface of the mandibular incisors to the incisal surface of the maxillary incisors covering them was measured ${ }^{24,25}$. The adolescents with vertical overlap exceeding $3.5 \mathrm{~mm}$ were classified with deep overbite ${ }^{1}$. The transverse occlusal alterations were diagnosed when the lateral occlusal relationships were incorrect. Crossbite of several or individual teeth, lateral edge-to-edge bite, and Brodie bite were also considered transverse occlusal changes ${ }^{15,25,26}$.

The Oral Health Impact Profile (OHIP-14) was used to evaluate the impact of malocclusion on the oral health-related quality of life (OHRQoL) of the adolescents. The OHIP-14 contains 14 questions that evaluate the following aspects: functional limitation, physical pain, psychological discomfort, physical disability, psychological disability, social disability, and deficiency. The responses were recorded according to the scale of codes and their respective meaning: $0=$ "never"; $1=$ "a few times"; $2=$ "sometimes"; $3=$ "almost always"; 4="always"23. For data analysis, the median was considered the cut-off point, meaning that higher scores indicated negative impact on OHRQoL ${ }^{27}$.

\section{Statistical analyses}

The association was tested between quality of life (outcome variable dichotomized by the median of the OHIP-14 score=3.85) and the sever- ity of malocclusion. For the other independent variables, the analysis was adjusted by the hierarchical multiple logistic regression model. For the severity of malocclusion, four groups were considered: G1 - DAI $\geq 3$, without transverse or deep bite problems; G2 - DAI $\geq 3$, with crossbite; G3 - DAI $\geq 3$, with deep bite; and G4 - DAI $\geq 3$, with Brodie bite.

In the conception of the hierarchical model, the first level included the variables of age and sex; the second level included parental level of education, income, and access; and the third level included severity of malocclusion (Figure 1). The levels of this model were determined based on hierarchical models used in the literature on health public issues ${ }^{9,22}$, which places sociodemographic variables in the first level, socioeconomic variables in the second level, clinical factors in the third level, and outcomes at the end of the model.

In the multiple logistic regressions, the variables with $\mathrm{p} \leq 0.20$ of each block were analyzed so that only the variables still associated with the OHIP-14, with $\mathrm{p} \leq 0.05$, remained in the model, after adjusting for the variables of the same block and for those that were hierarchically superior. From the logistic regression analysis, crude odds ratios were estimated and adjusted with the respective $95 \%$ confidence intervals. All the analyses were performed with the SAS software (Release 9.2, SAS Institute Inc., Cary, NC, USA).

\section{Results}

The total of 585 non-white adolescents were assessed to reach minimum sample size required. Thus, only the 217 non-white adolescents with severe malocclusion ( $\mathrm{DAI} \geq 3$ ) participated in the present study; of these adolescents, $46.5 \%$ were men, $65.9 \%$ had low family income, $60.8 \%$ had no access to dental care in the last year, and $49.8 \%$ of parents or guardians completed up to the eighth grade. The adolescents were divided into four groups: GI (DAI $\geq 3$ without transverse or deep bite problems), G2 (DAI $\geq 3$ with cross bite), G3 (DAI $\geq 3$ with deep bite) and G4 (DAI $\geq 3$ with Brodie bite).

The analysis was adjusted by the hierarchical multiple logistic regression model for the severity of malocclusion and the other independent variables, as shown in Table 1 . The adolescents with severe malocclusion ( $\mathrm{DAI} \geq 3$ ) divided into the G2, G3 and G4 showed p-value of 0.0501, 0.1475 , and 0.5407 , respectively, but did not remain in the final model. 


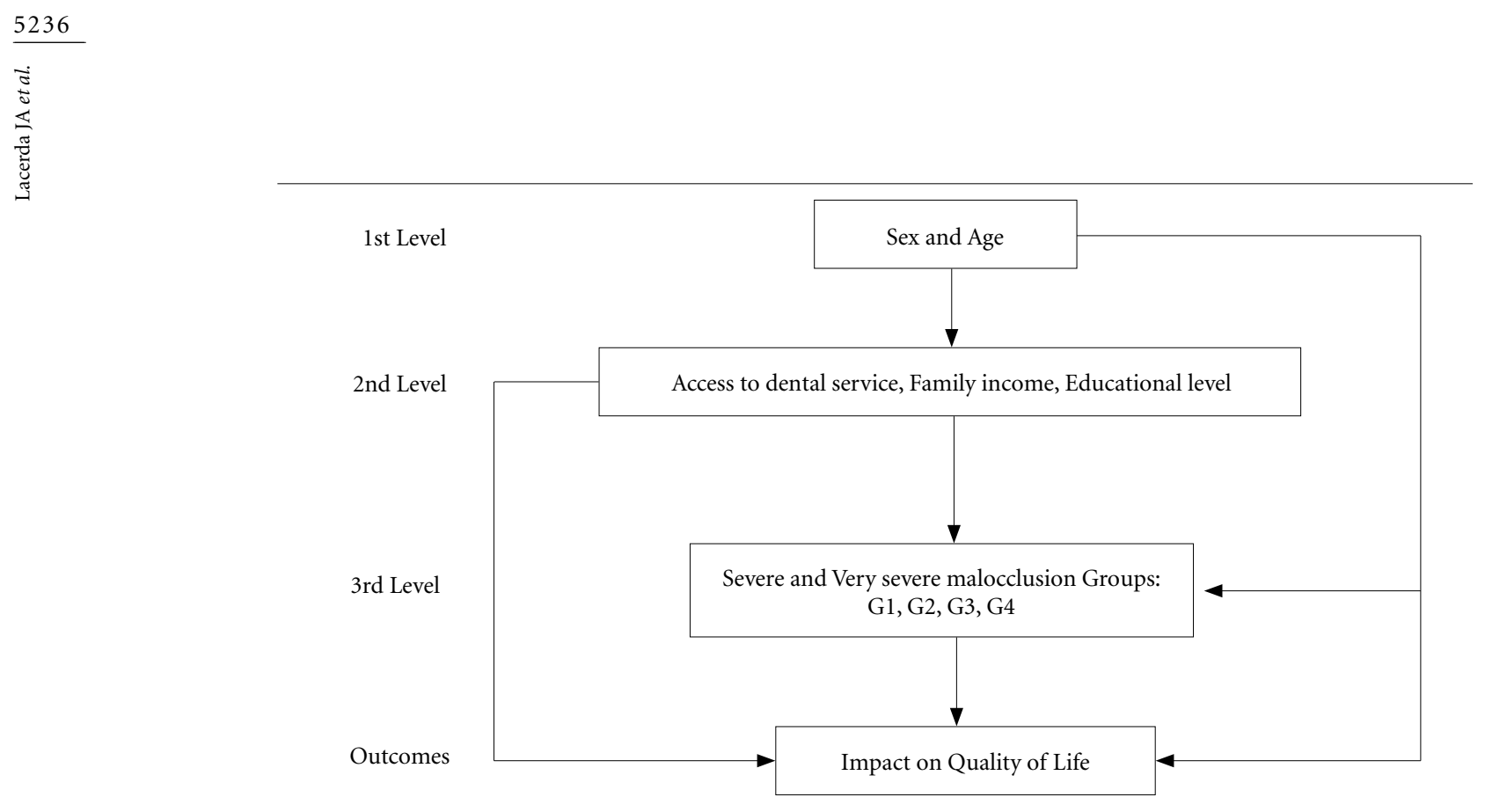

Figure 1. Theoretical model of the study.

Source: Elaborated by the authors.

Table 1. Individual and multiple analyses for the impact of the malocclusion severity on OHRQoL of non-white adolescents.

\begin{tabular}{|c|c|c|c|c|c|c|c|}
\hline \multirow[t]{2}{*}{ Variable } & \multirow[t]{2}{*}{ Category } & \multirow[t]{2}{*}{$\mathrm{N}(\%)$} & $\begin{array}{c}\text { OHIP-14 > } \\
\text { median }\end{array}$ & \multirow[t]{2}{*}{${ }^{*} \operatorname{Raw}$ OR ( $\left.{ }^{\$} \mathrm{CI} 95 \%\right)$} & \multirow{2}{*}{$\begin{array}{c}\text { p- } \\
\text { value }\end{array}$} & \multirow{2}{*}{$\begin{array}{l}\text { Adjusted OR } \\
\text { (CI95\%) }\end{array}$} & \multirow{2}{*}{$\begin{array}{c}\text { p- } \\
\text { value }\end{array}$} \\
\hline & & & Frequency (\%) & & & & \\
\hline \multicolumn{8}{|l|}{ 1st Level } \\
\hline \multirow[t]{2}{*}{ Age } & 12 years & $160(73.7)$ & $79(49.4)$ & 1 & & & \\
\hline & 15 years & $57(26.3)$ & $29(50.9)$ & $1.28(0.74-2.23)$ & 0.3722 & & \\
\hline \multirow[t]{2}{*}{ Sex } & Female & $116(53.5)$ & $63(54.3)$ & $1.48(0.86-2.53)$ & 0.1523 & & \\
\hline & Male & $101(46.5)$ & $45(44.6)$ & 1 & & & \\
\hline \multicolumn{8}{|l|}{ 2nd Level } \\
\hline Father's & Up to 8 th grade & $108(49.8)$ & $58(53.7)$ & $1.37(0.80-2.33)$ & 0.2491 & & \\
\hline Educational level & 1 year or longer & $109(50.2)$ & $50(45.9)$ & 1 & & & \\
\hline \multirow[t]{2}{*}{ Income } & $\leq$ median $(\mathrm{R} \$ 880)$ & $143(65.9)$ & $68(47.6)$ & $0.77(0.44-1.35)$ & 0.3643 & & \\
\hline & $>$ median & $74(34.1)$ & $40(54.0)$ & 1 & & & \\
\hline \multirow{2}{*}{$\begin{array}{l}\text { Access to dental } \\
\text { care in the last } \\
\text { year }\end{array}$} & No & $132(60.8)$ & $59(44.7)$ & $0.59(0.34-1.03)$ & 0.0634 & & \\
\hline & Yes & $85(39.2)$ & $49(57.6)$ & 1 & & & \\
\hline \multicolumn{8}{|l|}{ 3rd Level } \\
\hline \multirow[t]{4}{*}{ Severity } & $\begin{array}{l}\text { GI: DAI } \geq 3 \text { without } \\
\text { transverse or deep bite } \\
\text { problems }\end{array}$ & $73(33.6)$ & $43(58.9)$ & 1 & & 1 & \\
\hline & G2 DAI $\geq 3$ with cross bite & $33(15.2)$ & $13(39.4)$ & $0.45(0.20-1.05)$ & 0.0501 & $0.45(0.20-1.05)$ & 0.0501 \\
\hline & G3 DAI $\geq 3$ with deep bite & $89(41.0)$ & $41(46.1)$ & $0.60(0.32-1.11)$ & 0.1475 & $0.60(0.32-1.11)$ & 0.1475 \\
\hline & $\begin{array}{l}\text { G4 DAI } \geq 3 \text { with Brodie } \\
\text { bite }\end{array}$ & $22(10.1)$ & $11(50.0)$ & $0.70(0.27-1.82)$ & 0.5407 & $0.70(0.27-1.82)$ & 0.5407 \\
\hline
\end{tabular}

${ }^{\star}$ Odds ratio; ${ }^{s}$ Confidence Interval.

Source: Elaborated by the authors. 
Studies performed with non-white populations have assessed the traditional parameter of malocclusion determined by the DAI and, among the most prevalent occlusal changes, overjet and crowding stood out ${ }^{28}$. However, there is a lack of studies focusing on transverse problems and deep overbite, which are not discussed in the DAI and have an impact on orthodontic treatment need. The present study analyzed the more severe occlusal changes, because the perception of OHRQoL is modulated by the severity of malocclusion $^{4,7,29}$. Furthermore, when subdividing the adolescents with severe and very severe malocclusion according to the DAI and associating them with the absence or presence of transverse changes and deep bite, the study aimed to assess whether these changes could contribute to the difference regarding the impact on OHRQoL.

The demographic census of 2010 shows that half of the Brazilian population is composed by black and brown people ${ }^{23}$. This fact reinforces the significance of such approach, considering that Brazil presents the greatest number of Afro-descendants outside the African continent. Moreover, this population is socially disadvantaged and subjected to a condition of inequity regarding public health policies. Such inequity may be verified for the access to public health care, which associated with contextual aspects of income and education make this population more vulnerable to develop health problems ${ }^{30,31}$. Therefore, oral health presents the same impacts observed for general health, added by the problem that the public oral health care policy is recent ${ }^{32}$. Finally, this issue is so important for the discussion and advance of the Brazilian public health system that the Ministry of Health instituted in 2010 the "National Comprehensive Health Policy for the Black Population" ${ }^{30}$. Brazil needs epidemiological studies for the non-white population in order to decrease equities and develop the Brazilian public health system, thus promoting greater social justice.

As for transverse changes and deep bite, the literature has not yet established how these malocclusions influence quality of life. Some studies showed an association with deep bite ${ }^{33}$ and oth$\mathrm{ers}^{34-36}$ collaborated with the strong association of our findings. Divergent results have also been observed when assessing the impact of crossbite on quality of life. A previous study ${ }^{13}$ observed no negative impact of crossbite or Brodie bite on OHRQoL. However, these studies were conduct- ed with adult populations and high education and income levels.

According to the results obtained in the present study, none of the groups with severe malocclusion presented negative impact on OHRQol. It may be assumed that the difficulty for an individual to identify the relationship between deep and Brodie bites influences the absence of impact on quality of life. Brodie bite is generally perceived in more complex cases with skeletal involvement and/or a number of posterior teeth, and therefore it is difficult to correct ${ }^{16}$. Similarly, the functional and aesthetic consequences of deep bite are seen in more severe cases with nearly complete increased overlap associated with either tooth wear or the presence of gingival traumas.

The malocclusion that differentiated the groups assessed in the present study generally showed greater functional than aesthetic compromises. Nevertheless, it is worth noting that even though the DAI includes categories with aesthetic weight ${ }^{11}$, there are also factors with potential functional implications, such as tooth loss, molar relationship, and open bite, which compose the index and have an impact on severity.

Socioeconomic, cultural, and environmental issues are characteristic of the social determinants of health, and they may influence the health condition of a population ${ }^{37}$. Therefore, unfavorable socioeconomic conditions may be associated with a negative quality of life ${ }^{21,38}$. In the present study, the profile of the non-white population studied was characterized by low levels of income and education and by the lack of access to dental care, which exposed the condition of social inequality. The study also pointed out how the social determinants of health could explain the formulation of the health problem concept.

In this context, the perception of malocclusion might influence the access of the local health care system ${ }^{39,40}$. In addition, the effect of malocclusions on OHRQOL might depend on how prevalent other oral diseases are and how important dental aesthetics are seen in the sociocultural context of the population. Still according to the literature, children and their parents may have problems to relate malocclusion to oral health as most orthodontic conditions are asymptomatic ${ }^{39,41}$. In general, most orthodontic conditions are asymptomatic, hindering your perception; which justifies our choice for a population with severe malocclusion. This fact could explain the differences in the association of malocclusions with OHRQOL between Brazil and African countries ${ }^{40,41}$. 
Finally, it is a cross-sectional study, so the impact of malocclusion severity on quality of life was assessed in a set period of time. Longitudinal studies are suggested to assess the extension of such impact. Also, include dental caries in the model, due to its potential to negatively affect the OHRQoL.

In conclusion, malocclusion severity had no impact on the OHRQoL of non-white adolescents.

\section{Collaborations}

JA Lacerda participated in the data collection. SAS Vedovello, JA Lacerda, M Santamaria Junior and MC Meneghim participated in the development of research, data analysis and writing of the article. TMD Borges and M Vedovello Filho reviewed article. SAS Vedovello and MC Meneghim developed the statistical analysis. 


\section{References}

1. Cunha IP, Pereira AC, Frias AC, Vieira V, Meneghim MC, Batista MJ, Cortellazzi AL, Bulgareli JV. Social vulnerability and factors associated with oral impact on daily performance among adolescents. Health Qual Life Outcome 2017; 15:173-180.

2. Scapini A, Feldens CA, Ardenghi TM, Kramer PF. Malocclusion impacts adolescents' oral health-related quality of life. Angle Orthod 2013; 83(3):512-518.

3. Silva LFG, Thomaz EBAF, Freitas HV, Pereira ALP, Ribeiro CCC, Alves CMC. Impact of Malocclusion on the Quality of Life of Brazilian Adolescents: A population-based study. PLoS One 2016; 11(9):1-13.

4. Sun L, Wong HM, MacGrath CPJ. The factors that influence oral health-related quality of life in 15-year-old children. Health Qual Life Outcomes 2018; 16(1):19.

5. Ashari A, Mohamed AM. Relationship of the Dental Aesthetic Index to the oral health-related quality of life. Angle Orthod 2016; 86(2):337-342.

6. Santos PR, Meneghim MC, Ambrosano GMB, Vedovello Filho M, Vedovello SAS. Influence of quality of life, self-esteem on orthodontic treatment need. Am J Orthod Dentofacial Orthop 2017; 151(1):143-147.

7. Bittencourt J M, Martins LP, Bendo CB, Vale MP, Paiva SM. Negative effect of malocclusion on the emotional and social well-being of Brazilian adolescents: a population-based study. Eur J Orthodontic 2017; 39(6):628-633.

8. Sun L, Wong HM, McGrath CPJ. The factors that influence the oral health-related quality of life in 12-year-old children: baseline study of a longitudinal research. Health Qual Life Outcomes 2017; 15:1-14.

9. Peres KG, Frazão P, Roncalli AG. Epidemiological pattern of severe malocclusion in Brazilian adolescents. Rev Saude Publica 2013; 47(Supl. 3):1-9.

10. Javidi H, Vettore M, Benson PE. Does orthodontic treatment before the age of 18 years improve oral health-related quality of life? A systematic review and meta-analysis. Am J Orthod Dentofacial Orthop 2017; 151(4):644-655.

11. Cons NC, Jenny J, Kohout FJ. DAI: the dental aesthetic index. Iowa City: College of Dentistry, University of Iowa; 1986.

12. Jordão LMR, Vasconcelos DN, Moreira RS, Freire MCM. Individual and contextual determinants of malocclusion in 12-year-old schoolchildren in Brazilian city. Braz Oral Res 2015; 29(1):1-8.

13. Masood M, Suominen AL, Pietila T, Lahti S. Malocclusion traits and oral health-related quality of life in Finnish adults. Community Dent Oral Epidemiol 2017; 45(2):178-188.

14. Andrade AS, Gameiro GH, DeRossi M, Gavião MBD. Posterior Crossbite and Functional Changes. A Systematic Review. Angle Orthod 2009; 79(2):380-386.

15. Masood M, Masood Y, Newton T. Cross-bite and oral health related quality of life in young people. J Dent 2014; 42(3):249-255.

16. Chugh VK, Sharma VP, Tandon P, Singh GP. Brodie bite with an extracted mandibular first molar in a young adult: A case report. Am J Orthod Dentofacial Orthop 2010; 137(5):694-700.
17. Nasry HA, Barclay SC. Periodontal lesions associated with deep traumatic overbite. Br Dent J 2006; 200(10):557-561.

18. Bastos JL, Peres MA, Peres KG, Dumith SC, Gigante DP. Socioeconomic differences between self-and interviewer-classification of color/ race. Rev Saude Publica 2008; 42(2):324-334.

19. Telles EE, Lim N. Does it matter who answers the race question? Racial classification and income inequality in Brazil. Demography 1998; 35(4):465-474.

20. Gururatana O, Baker SR, Robinson PG. Determinants of children's oral-health related quality of life over time. Community Dent Oral Epidemiol 2014; 42(3):206-215.

21. Vedovello SAS, Ambrosano GMB, Pereira AC, Valdrighi HC, Vedovello Filho M, Meneghim MC. Association between malocclusion and the contextual factors of quality of life and socioeconomic status. Am J Orthod Dentofacial Orthop 2016; 150(1):58-63.

22. Bulgareli JV, Faria ET, Cortellazzi KL, Guerra LM, Meneghim MC, Ambrosano GMB, Frias AC, Pereira AC Factors influencing the impact of oral health on the daily activities of adolescents, adults and older adults. Rev Saude Publica 2018; 52:44.

23. Instituto Brasileiro de Geografia e Estatística (IBGE). Censo demográfico 2010: Características Gerais da População, Religião e Pessoas com Deficiência. Rio de Janeiro: IBGE; 2011.

24. Luzzi V, Ierardo G, Corridore D, Di Carlo G, Di Diorgio G, Leonardi E, Campus GG, Vozza I, Polimeni A Bossù $M$. Evaluation of the orthodontic treatment need in a pediatric sample from Southern Italy and its importance among pediatricians for improving oral health in pediatric dentistry. J Clin Exp Dent 2017; 9(8):995-1001.

25. Brook PH, Shaw WC. The development of an index of orthodontic treatment priority. Eur J Orthod 1989; 11(3):309-320

26. Grabowski R, Stahl F, Gaebel M, Kundt G. Relationship between occlusal findings and orofacial myofunctional status in primary and mixed dentition. Part I: prevalence of malocclusions. J Orofac Orthop 2007; 68(1):26-37.

27. Slade GD. Derivation and validation of a short-form oral health impact profile. Community Dent Oral Epidemio 1997; 25(4):284-290.

28. Siluvai S, Khetrimayuma N, Reddy CVK, Siddannac S, Manjunathd M, Rudraswamyd S. Malocclusion and related quality of life among 13- to 19-year-old students in Mysore city -A cross-sectional study. Oral Health Prev Dent 2015; 13(2):135-141.

29. Farias ACR, Cangussu MCT, Ferreira RFA, Castelucci M. Occlusal characteristics and orthodontic treatment need in black adolescents in Salvador/BA (Brazil): An epidemiologic study using the Dental Aesthetics Index. Dental Press J Orthod 2013; 18(1):34e1-34e8.

30. Brasil. Ministério da Saúde (MS). Política Nacional de Saúde Integral da População Negra: uma política do SUS. 3a ed. Brasília: MS; 2017.

31. Chor D, Lima CRA. Aspectos epidemiológicos das desigualdades raciais em saúde no Brasil. Cad Saude Publica 2005; 21(5):1586-1594. 
32. Guiotoku SK, Moysés ST, Moysés SJ, França BHS, Bisinelli JC. Iniquidades raciais em saúde bucal no Brasil. Rev Panam Salud Publica 2012; 31(2):135-141.

33. Jung M. An evaluation of self-esteem and quality of life in orthodontic patients: Effects of crowding and protrusion. Angle Orthod 2015; 85(5):812-819.

34. Araki M, Yasuda Y, OgawaT, Tumurkhuu T, Ganburged G, Bazar A, Fujiwara T, Moriyama K. Associations between malocclusion and Oral Health-Related Quality of Life among Mongolian Adolescents. Int J Environ Res Public Health 2017; 14(8):1-10.

35. Bernabé E, Sheiman A, de Oliveira, CM. Impacts on daily performances attributed to malocclusion by British adolescents. J Oral Reabil 2009; 36(1):26-31.

36. Fabian, S, Gelbrich, B, Hiemisch, A, Kiess W, Hirsch C. Child study team. Impact of overbite and overjet on oral health-related quality of life of children and adolescents. J Orofac Orthop 2018; 79(1):29-38.

37. Brizon VSC, Cortellazzi, KL, Vazquez FL, Ambrosano GMB, Pereira AC, Gomes VE. Individual and contextual factors associated with malocclusion in Brazilian children. Rev Saude Publica. 2013; 47(Supl. 3):118128.

38. Benson PE, Da'as T, Johal A, Mandall NA, Williams AC, Baker SR, Marshman Z. Relationships between dental appearance, self-esteem, socio-economic status, and oral health-related quality of life in UK schoolchildren: A 3-year cohort study. Eur J Orthod 2015; 37(5):481-490.

39. Kragt L, Dhamo B, Wolvius EB, Ongkosuwito EM. The impact of malocclusions on oral health-related quality of life in children-a systematic review and meta-analysis. Clin Oral Investig 2016; 20(8):1881-1894.

40. Sischo L, Broder HL. Oral health-related quality of life: what, why, how, and future implications. J Dent Res 2011; 90(11):1264-1270.

41. O’Brien K1, Kay L, Fox D, Mandall N. Assessing oral health outcomes for orthodontics--measuring health status and quality of life. Community Dent Health 1998; 15(1):22-26.

Article submitted 29/06/2018

Approved 04/12/2019

Final version submitted 06/12/2019

Chief editors: Romeu Gomes, Antônio Augusto Moura da Silva 